\title{
CRANIOFACIAL
}

\section{How I Do It : Bilateral Cleft Lip Repair}

\author{
Gentur Sudjatmiko, Sweety Pribadi \\ Jakarta, Indonesia
}

\begin{abstract}
Several techniques have evolved to achieve better outcomes in bilateral cleft lip repair. The techniques performed should overcome the challenge presented in bilateral cleft lip, such as protrusion of premaxilla, the short columella, the wide gap, minimal dry mucosa in prolabium also the low socioeconomic level that typically presented in cleft patient. Considering the challenges mentioned above, a proper design and precise technique should be defined. We proposed a design and technique with promising results, which involves: 1) The precision of the design, the adjustable point of the design to modify lateral flap will provide adequate thickness of vermillion to create tubercle as well as to provide adequate tissue for nasal floor. 2) The possibility to approximate the orbicularis oris muscle although the premaxilla is protruded. It is beneficial and cost-effective for the patients who cannot afford preoperative orthodontic treatment. 3) The suggestion to not worry about the immediate postoperative result as it will evolve to a satisfactory result. 4) The use of non-absorbable nylon 5.0 and 6.0 for the whole layers will overcome tension and reduce cost.
\end{abstract}

Keywords: Bilateral Cleft Lip Repair, Design, and Surgery Technique

Abstrak: Beberapa teknik operasi bibir sumbing bilateral telah berevolusi untuk mencapai hasil yang lebih baik. Teknik operasi yang dilakukan diharapkan dapat mengatasi tantangan yang ada pada bibir sumbing bilateral, yaitu protrusi dari premaksila, kolumela yang pendek, celah yang lebar, sedikitnya bagian bibir kering di prolabium, serta level sosioekonomi menengah ke bawah yang tipikal pada pasien sumbing. Mempertimbangkan tantangan-tantangan di atas, sebuah disain yang sesuai dan teknik yang tepat perlu dikembangkan. Kami menawarkan sebuah disain dan teknik dengan hasil yang menjanjikan, yaitu: 1) Disain yang presisi untuk memodifikasi flap lateral, dengan titik yang dapat diatur kemudian, akan menghasilkan ketebalan yang cukup dari vermilion untuk membuat tuberkel juga menyediakan jaringan yang cukup untuk dasar hidung. 2) Kemungkinan untuk mengaproksimasi otot orbicularis oris meskipun terdapat protrusi premaksila. Hal ini sangat bermanfaat dan lebih efisien untuk pasien yang tidak mampu membiayai penggunaan alat ortodontik preoperatif. 3) Anjuran untuk tidak mengkhawatirkan mengenai hasil langsung pascaoperasi karena selanjutnya hasilnya akan tampak lebih memuaskan. 4) Penggunaan benang nylon 5.0 dan 6.0 yang tidak diserap untuk seluruh lapisan jaringan akan mengatasi tegangan dan mengurangi biaya bahan habis pakai.

Kata Kunci : Bilateral Cleft Lip Repair, Design, and Surgery Technique

Received: 10 May 2013, Revised: 3 June 2013, Accepted: 9 June 2013.

(Jur.Plast.Rekons. 2013;2:58-63)

ilateral cleft lip repair is a procedure recognized by plastic surgeons as more difficult than unilateral cleft lip. Also, the outcome of the repaired bilateral cleft lip remains noticeable compared to unilateral cleft lip. Therefore, many plastic surgeons should advance their techniques to maximize the outcome. The expected results of bilateral cleft lip repair stay the same among plastic surgeons: to achieve corrected lips with minimal scar and to resemblance the normal lips by anatomy, symmetry, and muscle function, as well as maxillary growth in normal condition.

Several techniques have evolved to achieve better outcomes in bilateral cleft lip repair. The techniques performed are hoped to overcome the numerous challenges
Disclosure: The authors have no financial interest to declare in relation to the content of this article. 
presented due to anatomy of bilateral cleft lip deformity. The first problem encountered is due to the uncontrolled growth of the premaxillary suture during fetal growth resulting in over projection of the premaxilla, sometimes accompanied by rotation and angulation for almost 90 degrees to the plane of the lip (Figure 1). ${ }^{1}$ This situation will influence the tension on the repair, the degree of dissection required, as well as the final aesthetic result.2 The second problem presented is the short columella, whereas the recession of the medial crural footplates along the lateralization of the domes, and deficient skin produce the typical absent and short columella. ${ }^{2}$ This condition make difficulties to reconstruct both of the central upper lip and the collumellar length resulting the imperfect nose which requires another secondary rhinoplasty in their older age. The third problem is the wide gap in complete bilateral cleft, that if it repaired under tension can result in a tight lip with inadequate lip elements, often with a thin vermillion and whistle deformity. ${ }^{3}$ Lastly, minimal dry mucosa in the prolabium gives difficulties to form the vermilion and tubercle. ${ }^{1}$

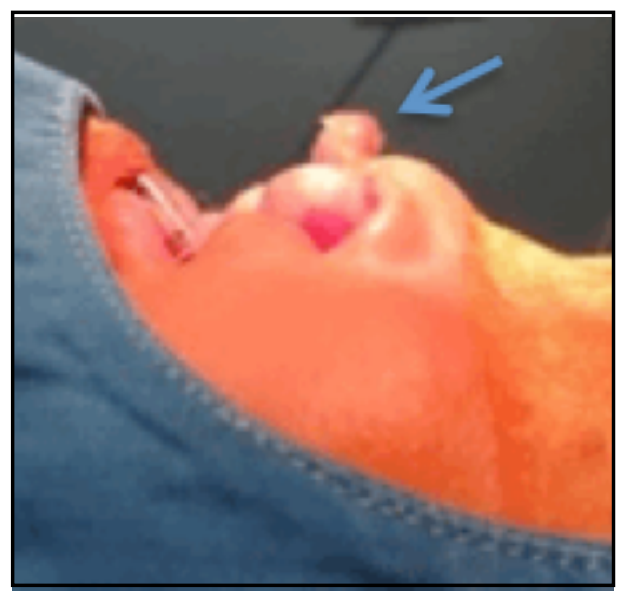

Figure 1. Note the premaxilla protrution (blue arrow)

This author's design and technique was made from modification of previous technique, aims to become the leading technique in correcting bilateral cleft lip with its ability to overcome several problems mentioned above. The principles of the technique are the adjustable lateral flap to overcome the wide gap and to provide adequate tissue thickness for vermillion and nasal floor, the possibility to approximate the orbicularis oris muscle above the premaxilla, the suggestion to not worry about the immediate postoperative result as it will evolve to a satisfactory result, and the use of non-absorbable nylon 5.0 and 6.0 for the whole layers that will overcome tension and reduce cost. The detailed design and surgical technique proposed, mentioned below:

\section{Author's Design and Surgical Technique}

The following points are marked while the skin is slightly stretched during marking (Figure 2). The highest points of the cupid bow are point 1 and 3 . The lowest point of the cupid bow is 2 while distance between points $1-2=$ points $2-3$ is about 2 until $3 \mathrm{~mm}$. The lateral columella marked with point 4 (point $1+1 \mathrm{~mm}$ laterally) and point 5 (point $3+1 \mathrm{~mm}$ laterally). Point 6 and $6^{\prime}$ marked the medial side of alar base. Point $4^{\prime}$ and $5^{\prime}$ are the projection of the cleft side of point 4 and 5 while the distance between point $6-4=6-4^{\prime}$ and point $6-5=6-5^{\prime}$. Point $1^{\prime}$ and $3^{\prime}$ are projection of the cleft side of point 1 and 3 while the distance between 1-4 = $1^{\prime}-4^{\prime}$ and 3-5 = 3'-5'. Point $2^{\prime}$ and $2^{\prime \prime}$ are the projection in both of cleft side, while the distance between point $1^{\prime}-2^{\prime}=1-2=2-3=2^{\prime \prime}-3^{\prime}$. Point 7,8 , and 9 are the extended incision point from point 1,2 , and 3 to prolabium. Point $8^{\prime}$ and $8^{\prime \prime}$ marked the vermilion thickness, measured vertically from point $2^{\prime}$ and $2^{\prime \prime}$. Point A and B indicate the lateral side from alar cartilage. The common incision design by other surgeon showed by the red line in the picture (Figure 2), which follow the alar base. In this paper, the author propose a design by making the incision from point $\mathrm{A}$ to $4^{\prime}$ or $\mathrm{B}$ to $5^{\prime}$ to give adequate tissue to make the base of the nostril. In wide bilateral cleft, point $\mathrm{A}-4^{\prime}$ or $\mathrm{B}-5^{\prime}$ is adjustable depends on the wide of the gap in order to fill the nasal base with enough tissue. The design is not required to be curved around alar base, instead put downward so there are enough tissues to cover the gap, and meet the prolabium. (Figure 3). 


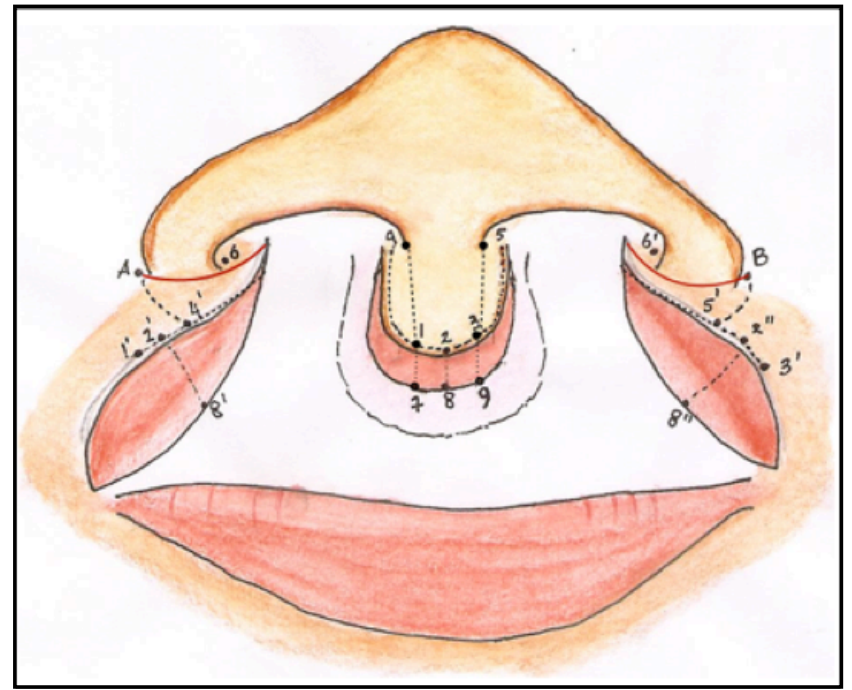

Figure 2. Illustration of surgical design of complete bilateral cleft lip repair. Author does not use the red line just below the alar base.

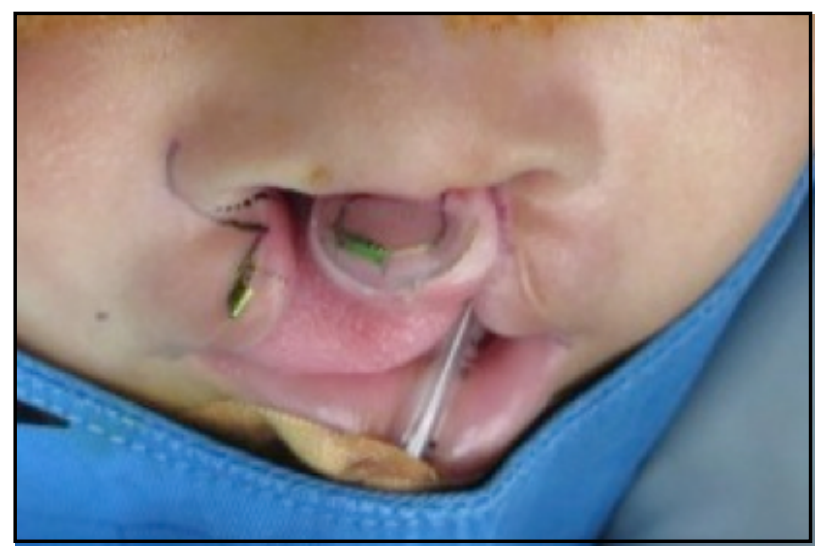

Figure 3. Incision design in the right side of patient. White line in the prolabium is replaced by the one on lateral side

Anesthetic and vasoconstrictor agents are injected on the incision area to reduce bleeding and also to mark the important points or tattooing (Figure 4). Before initiating the incision, it is better to wait for several minutes until the tissue look pale to distinguish the tissue easily. Too much infiltration of anesthetic agent and vasoconstrictor will cause disorientation in flap incision.

Start the incision from skin through the muscle, but do not incise through the mucosal layer. The excess tissues were discarded later to anticipate any tissue insufficiency. The blades were positioned to face the oral (away from operator) so that the incision is easily visible without blocked by operator hand.

Orbicularis oris muscles were dissected sharply from the lateral flap side to make the flap B, then the muscle were dissected away toward nasolabial sulcus, so that the muscles could be stretched to the center of the premaxilla (Figure 5). 
Flap A is made by dissecting prolabium from the premaxilla. According to the design, the area was divided into 3 parts (Flap C1, A, and C2). Flap A, C1 and C2 were elevated off the premaxilla, make sure all the flaps were elevated from their base tissue (Figure 6). If the prolabium is too small or the gap is not too far, flap C could be discarded or used to make the base of the muscle. Suture the mucosa from the base of the flaps so there were no raw surfaces on the mucosal covered area.

Try to adjoin point 4 to point $4^{\prime}$ and stitch it with nylon 5.0 to made the nasal floor (Figure 5). The purpose is to hold the traction between those flaps and to prevent widening of the wound edge as well as the scar.

Stitch the oral part of the nasal floor followed by stitching the nasal part (Flap C). Try to make adjustment between the edges so

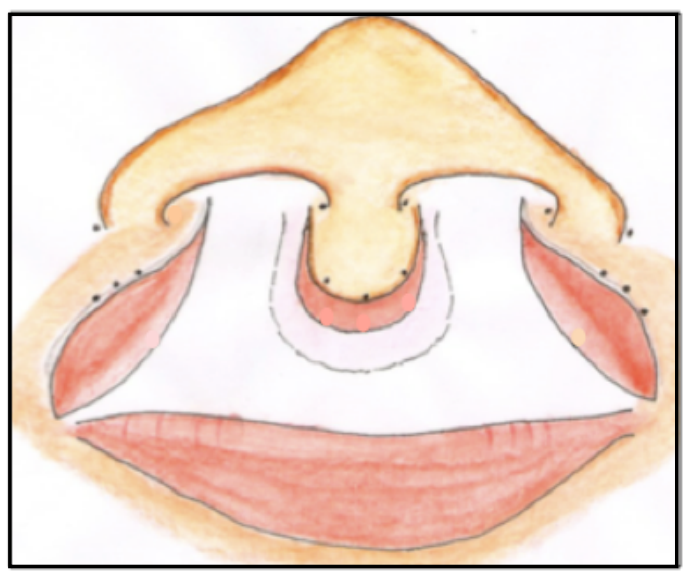

Figure 4. Anesthetic and vasoconstrictor agent injection on the design using insulin syringe (tattooing).

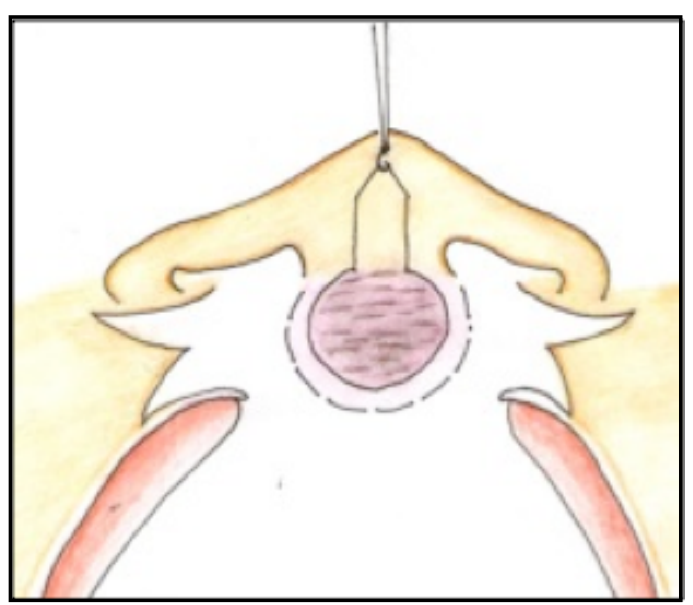

Figure 6. Flap $A$ is elevated from their base tissue. In this picture, there was no Flap $C$ to fulfill below the alar base. that the nostril was not collapse. This part is very important to adjust the diameter of the nostril, since normal respiration in babies $60 \%$ were done through the nose.

Suture the mucosa from flap B1 and flap B2 to the mucosal area in the center. The prolabium can be fold when needed. Suture the orbicularis oris muscle on flap B in the middle of prolabium, with minimum of three sutures using monofilament non-absorbable 5.0 (Figure 5). This technique will overcome the protrusion of the premaxilla, which is beneficial and costeffective for the patients who cannot afford preoperative orthodontic treatment.

Control suture was done to the vermillion muscle to have a symmetrical configuration (Figure 8). The muscle and a little dermis of Flap B was stitched in the middle of prolabium (point 1 to $1^{\prime}$ and point 4 to $4^{\prime}$ )

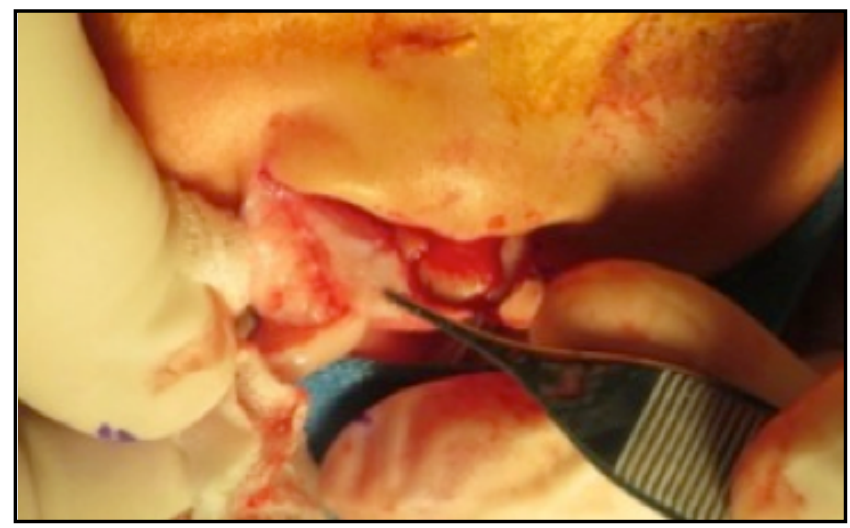

Figure 5. Orbicularis oris muscles are dissected from the skin on lateral flap.

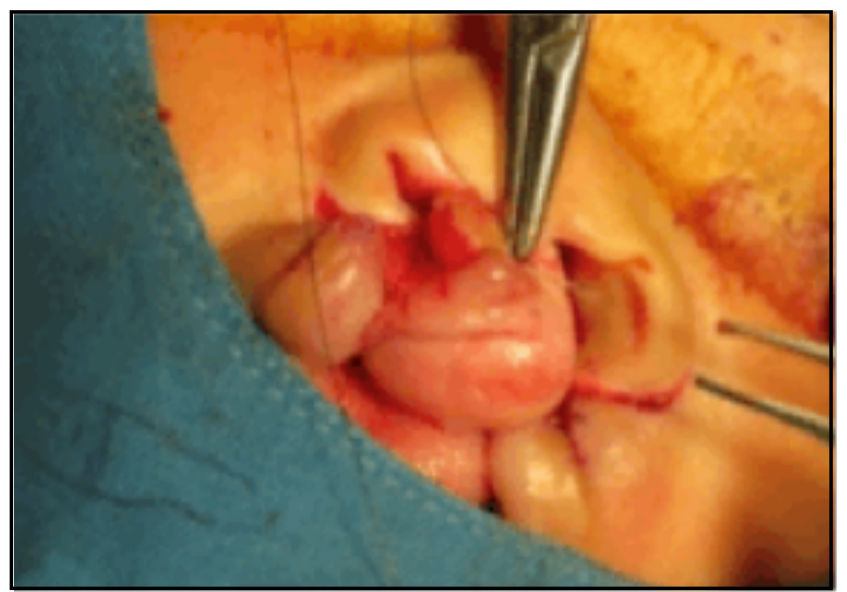

Figure 7. Adjoin point 4 to $4^{\prime}$ and stitch it together to make the nasal floor. 


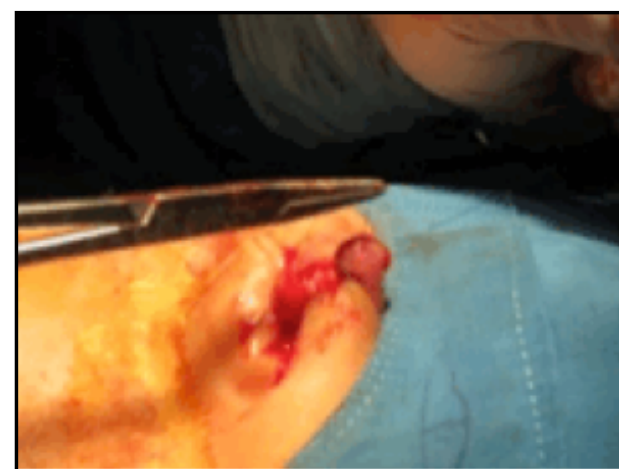

Figure 8. Control Suture was done to the vermillion muscle to have a symmetrical configuration

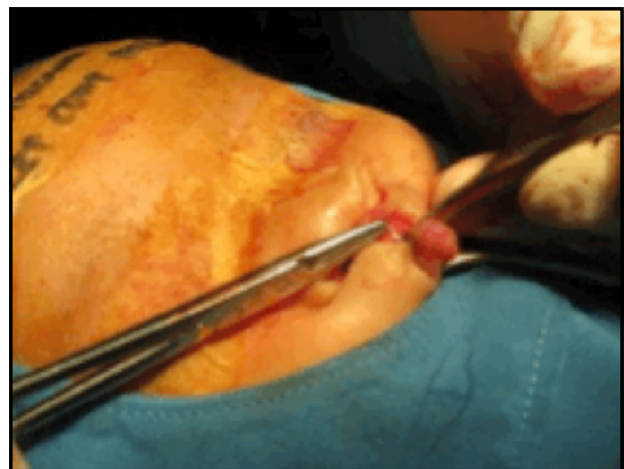

Figure 9. Stitch the muscle and a little dermis of Flap $B$ in the middle of prolabium. One stitch is usually enough

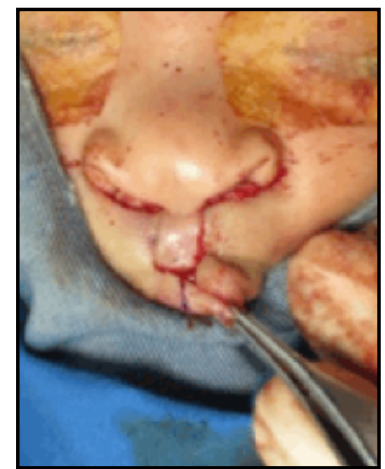

Figure 10. Estimate and design the line to create tubercle of vermillion, then incise the purple line.
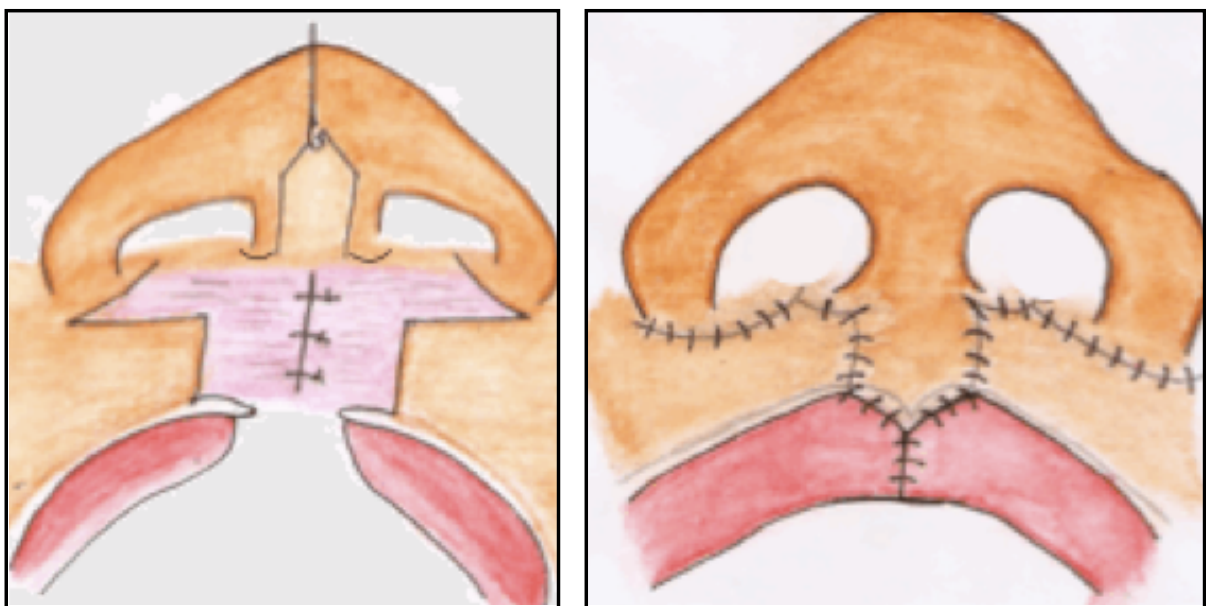

Figure 11. Left : Stitch the muscle with 5.0-monofilament non-absorbable thread.

Right : outer skin layer with 6.0-monofilament non-absorbable thread base.
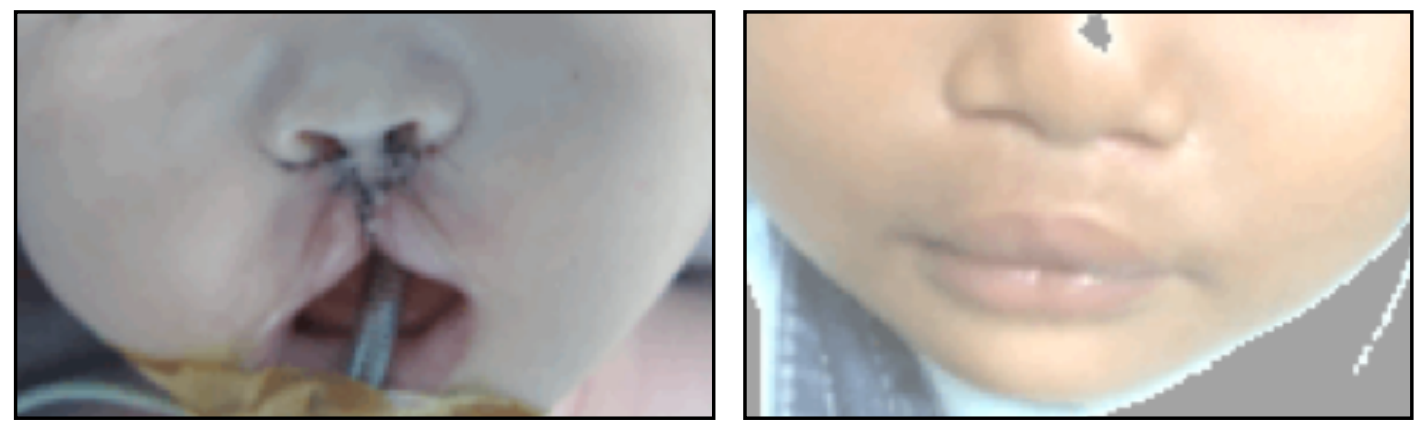

Figure 12. Left : Immediate post-op results. Right : follow-up result after 6 months (right). Note the healing process as time passed, the upper lip will align with the lower lip. 
(Figure 9). We estimate and design the line to create tubercle of vermillion, then incise the purple line (figure 10) .

The outer skin sutures performed with monofilament non-absorbable 6.0 suture. The use of non-absorbable nylon 5.0 and 6.0 for the whole layers will overcome tension and reduce the surgery cost due to their affordable price (Figure 11).

The immediate postoperative result usually shows the upper lip tends to retract to upright position. We should not be worried about this condition since it will evolve satisfactory by the time passed, as the healing of the upper lip will move downward and align with the lower lip (Figure 12).

In bilateral cleft lip, nasal reconstruction is not done together with lip reconstruction (different with unilateral cleft lip). As time passed, the nose can evolve into a better shape, showed by elongation of the columella and the rising of the nasal tip.

\section{Gentur Sudjatmiko}

Plastic Surgery Division

Cipto Mangunkusumo General National Hospital

Jalan Diponegoro.No.71, Gedung A, Lantai 4.

dr_gentur@yahoo.co.id

\section{REFERENCES}

1. Hoffman WY. Cleft Lip Repair. In: Serleti JM, Taub PJ, Wu LC, ed. Current Reconstructive Surgery. China: Mc Graw-Hill; 2013:129-31.

2. Hopper RA, Cutting C, and Grayson B. Cleft Lip and Palate. In: Thorne CH, Beasley RW, Aston SJ, Eds. Grabb and Smith's Plastic Surgery. 6th Edition. Philladelphia: Lippincott Williams and Wilkins; 2007: 203-15.

3. Kalanzi, E.W, Gati GL, and Massei A. The Role of Lip Adhesion in Treatment of Cleft Lips. East and Central African Journal of Surgery. 2004; 9(2):61-6. 